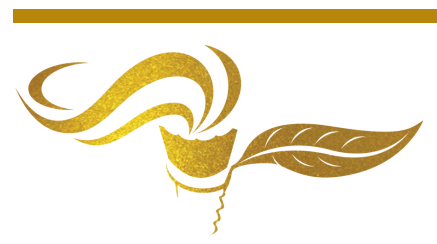

\title{
Transdisciplinarity and Transpraxis
}

\section{Sue L. T. McGregor}

ATLAS Fellow, Professor Emerita (MSVU), McGregor Consulting Group (Principal Consultant), 11565 Peggy's Cove Road, Seabright Nova Scotia Canada B3Z 2Y1, Email:sue.mcgregor@msvu.ca or www.consultmcgregor.com

Received 5 November, 2019; Revised March 5, 2020; Accepted March April 4, 2020

Available online 9 April, 2020 at www.atlas-journal.org, doi: 10.22545/2020/00134

\begin{abstract}
- his paper represents an inaugural attempt to relate transpraxis to transdisciplinarity. After providing overviews of Nicolescuian transdisciplinarity (especially ontology), praxis, and transpraxis, their juxtaposition revealed that augmenting transdisciplinarity with transpraxis and vice versa is a noteworthy addition to both strands of thought. Transdisciplinarity gains reflexivity, dialogic exchange, transpraxis space, contingent universalities and provisionality, and the notion of deconstructing self-serving hierarchies. Transpraxis gains a rich methodology for creating new knowledge emergent from deconstructing self-serving hierarchies and binaries. It is enriched with the zone of nonresistance, the unifying Hidden Third, and a richer notion of resistance in the form of multiple levels of Reality. Researchers and practitioners are encouraged to build on the narrative shared in this paper and conceptualize the neologism transdisciplinary transpraxis as a new phenomenon.
\end{abstract}

Keywords: Transdisciplinarity, transpraxis, praxis, Nicolescuian ontology, transdisciplinary transpraxis.

\section{Introduction}

Transdisciplinary (TD) initiatives involve collaboration amongst academics, governments, business enterprises and civil society (McGregor, 2017; Nicolescu, 2002) [1, 2]. Their success depends on praxis, which is a unity of practice, reflection and theory (Evans, 2015) [3]. These three aspects of praxis are nonlinear and nonhierarchical meaning that "each can influence or serve as a generating point for activity in the other two realms of praxis" (Evans, 2015, p. 73 [3]). Reciprocally, any outcomes arising from praxis require transdisciplinarity (Evans, 2015) [3].

Mitchell and Moore (2015, p. 31 [4]) recently coined the term "transdisciplinary praxis" as it pertains to how universities can do transdisciplinarity. Their work using this neologism informs the child and youth studies field (see also Mitchell \& Moore, 2018) [5]. TD praxis is actualized through (a) participatory dialectics and sufficiently shared principles, (b) moving beyond comfort zones while remaining open to multiple perspectives, (c) working across formal and informal contexts, (d) a respect for complexity, (e) being humble and collegial and (f) emergent collective action that is community centric and critically conscious (Mitchell \& Moore, 2015) [4].

This paper concerns transdisciplinary transpraxis, a neologism (i.e., a newly constructed term). A March 2020 Google Boolean search using this phrase yielded zero results. Transpraxis, an extension of praxis, was 
Sue L. T. McGregor

Transdisciplinarity and Transpraxis

developed by criminology scholars (Arrigo \& Bersot, 2016; Henry \& Milovanovic, 1994; Milovanovic, 1997) $[6,7,8]$. This paper explores the potential of bringing transpraxis to transdisciplinary work and vice versa. The discussion includes an overview of Nicolescuian transdisciplinarity (especially the ontology axiom), a synopsis of praxis and transpraxis, and a discussion of how transpraxis and transdisciplinarity enrich each other. The paper adds another layer to the already complex nature of both transdisciplinarity and transpraxis.

\section{Nicolescuian Transdisciplinarity}

This discussion is informed by Nicolescu's $(2002,2014)[2,9]$ transdisciplinary methodology (i.e., a new way to create knowledge relative to empirical, interpretive and critical methodologies, see McGregor, 2018) [10]. Nicolescu formulated transdisciplinarity as a way to overcome the inadequacies of mono, multi and interdisciplinarity in addressing the complex, wicked problems humanity faces (e.g., climate change, unsustainability, poverty, health crises, loss of diversity, terrorism). Wicked problems are hard to define and harder to solve because they are multi causal and multi stakeholder; trying to fix them usually creates even more wicked problems yet something must be done (McGregor, 2019; Rittel \& Webber, 1973) [11, 12].

Nicolescu's TD methodology comprises three philosophical axioms: (a) multiple levels of Reality (internal and external to humans) whose interaction is mediated by the Hidden Third, an invisible unifying force (ontology); (b) knowledge as complex, emergent, cross fertilized and embodied (epistemology); and (c) inclusive logic (and the logic of complexity) to both temporarily reconcile contradictions inherent in multiple perspectives and integrate different ways of knowing into new transdisciplinary knowledge (Nicolescu, 2002, 2014) [2, 9]. Ontology is of special interest to this discussion; see McGregor (2018) [10] for an overview of the other axioms, including axiology (values).

\subsection{Transdisciplinary Ontology: Multiple Levels of Reality and the Hidden Third}

Ontology (Greek ontos, 'to be') is a branch of philosophy that studies the nature of reality (having existence or substance), the world, being, and becoming (McGregor, 2018) [10]. Nicolescu's (2002) [2] ontological formulation is of interest to this discussion of transdisciplinary transpraxis because reality is where key transpraxis notions seem to come into play: resistance, mutual struggle, becoming, and shared meanings (Arrigo, 2006; Arrigo \& Bersot, 2016) [6, 13]. Classical science assumes there is one reality waiting to be discovered using the scientific method (McGregor, 2011a, 2018) [10, 14]. Nicolescu (who capitalizes Reality) formulated Reality as a "multileveled structure" (2014, p. 31 [9]) comprising the TD-Subject, TD-Object, and the Hidden Third.

In a general sense, subjective refers to personal opinions, assumptions, interpretations, beliefs, points of view, values, emotions and judgments. These are internal to humans. Objective refers to information or analysis that is fact based, measurable and observable. This is external to humans. If something is subjective, it is based on personal feelings (emotional). If it is objective, it is based on facts (evidence) (Anderson, 2014; McGregor, 2018; "Subjective vs objective," 2019) [10, 15, 16]. In Nicolescuian transdisciplinarity, Reality exists in both the internal (TD-Subject) and external (TD-Object) world of humans and any movement between them requires lubrication via the Hidden Third (Nicolescu, 2002) [2] (see Figure 1). The convention of adding the adjective TD and a hyphen to the nouns subject and object serves to create two new words distinguishing them from their general meaning. The TD-Subject and TD-Object arise from a transdisciplinary space rather than life in general.

\subsubsection{Internal level of Reality (TD-Subject).}

Reality in the internal world of humans - the TD-Subject - is where people's subjective consciousness, worldviews and perspectives flow. These Realities comprise political, social and cultural, historical, and individual (psychological and philosophical). The TD-Subject pertains political and ideological; social to peoples, communities and societies' individual, collective and generational lived experiences, stories and 


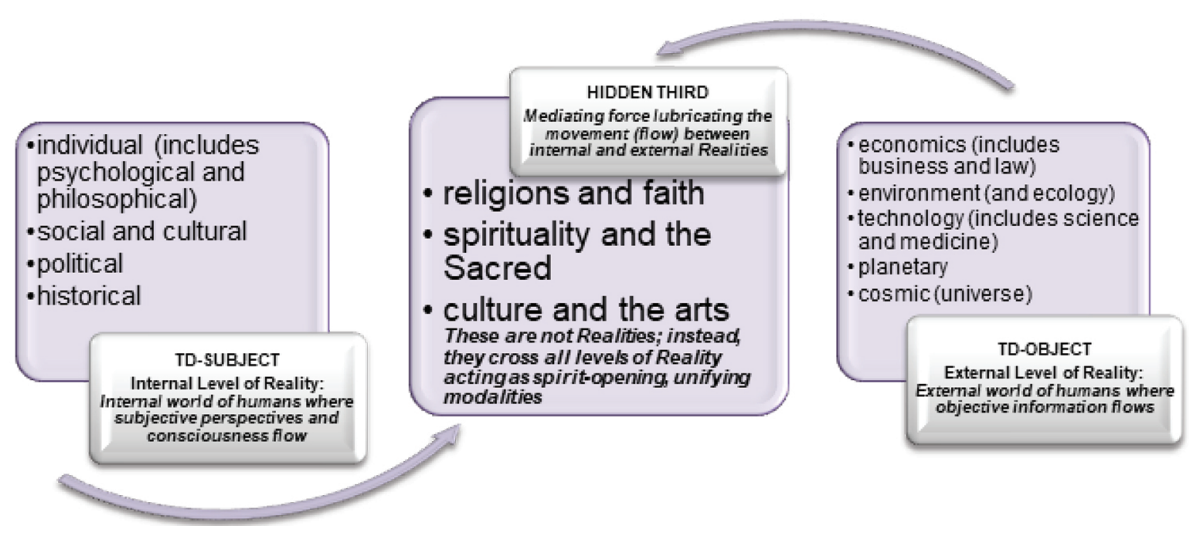

Figure 1: Nicolescuian transdisciplinary ontology.

narratives. This internal realm represents the flow of subjective (emotional) perceptions and consciousness (i.e., internal information). Unlike the TD-Object, the TD-Subject is "totally dependent on the mind for existence" (McGregor, 2018, p. 191 [10]). The flow of human consciousness is "an ascending movement, energising and self-willed" (Nicolescu, 2016, p. 18 [17]).

\subsubsection{External level of Reality (TD-Object)}

Realities external to humans - the TD-Object - are where objective information flows with supportive facts, observations, statistics and evidence. This level of Reality comprises environment (and ecology), economics (including business and law), technology (including science and medicine), planetary, and cosmic (beyond the planet to the universe). These Realities are perpetuated by academic disciplines, industries, science and innovation, and likeminded governments informed by imperialism, positivism, capitalism, globalization, and materialism (Nicolescu, 2014) [9].

Nicolescu (2014) said that the "unbridled development" (p. 9) and "overwhelming advance of technoscience" (p. 11) [9] (his characterization of the TD-Object) is "without brakes, without values, without any end other than utilitarianism" (p. 101) [9] (e.g., useful and functional no matter the cost of producing it). "When the greater good for the greatest number is one's goal, then nearly any means to that end becomes defensible. . . . That is the logic of utilitarianism" (Mitchell, 2004, para. 3; see also Sinnott-Armstrong, 2019) $[18,19]$.

\subsubsection{The Hidden Third (unifying force)}

Appreciating the inherent, divisive tension between subjective internal (value-laden) perceptions and objective external (value-free) information, a tension that precludes easy reconciliation when addressing problems, Nicolescu (2000, 2006a, 2011) [20, 21, 22] formulated the Hidden Third as a zone of nonresistance to others' views on Reality. A zone signifies an area that is distinguished on the basis of particular characteristics (Anderson, 2014) [15]. In transdisciplinarity, the it zone of nonresistance is characterized as playing the mediating role of 'a third party' between presumably complementary Realities. It acts like a secretly included middle agent (i.e., a unifier) that allows for temporary unification of, what is normally, contradictory ideas (Nicolescu, 2005) [23].

The TD zone of nonresistance comprises (a) culture (collectively regarded manifestation of human intellectual and art achievements); (b) art (aesthetics, creative expression and the nature of beauty); (c) religions (historical and cultural systems and rituals built around a deity); (d) faith (individual's belief in the deity or the religious system); (e) spirituality (essential essence of humanity - an inner force) and (f) the Sacred (absolute respect for others and an awareness of being linked by a shared common life) (Nicolescu, 2002, 2014, 2016) [2, 9, 17]. These are not Realities; instead, crossing all levels of Reality, these 
Sue L. T. McGregor

Transdisciplinarity and Transpraxis

aspects of human life help to reduce modernistic dualism and fragmentation; that is, the Hidden Third reduces the tension between people and lessens their resistance to temporarily setting aside their worldview and embracing others' viewpoints.

\subsubsection{Transdisciplinary resistance}

Transdisciplinary ontology is all about resistance. Generally speaking, resist is Latin resistere, 'to stop' (Harper, 2020) [24]. To resist means to oppose and/or experience unwillingness or unresponsiveness to changes in states of motion or rest. The capital $\mathrm{R}$ version of Reality used in the Nicolescuian TD methodology reflects "the reality that resists our experiences, representations, descriptions, images, and mathematical formulations" with and of the world (Nicolescu, 2014, p. 105 [9]). It resists the way we currently know the world (i.e., our current reality). When addressing a wicked problem, people cannot move their points of reference back and forth between different Realities unless they can engage with their natural resistance to new insights, perceptions and vantage points that challenge their current reality (Cole, 2006) [25].

Nicolescu (2011) [22] realized that resistance is inherent in perspective shifting, which involves moving from one Reality to another and connecting with unfamiliar or antagonist modes of thinking and viewpoints. Overcoming resistance thus also involves awareness of one's own habitual thought patterns (e.g., paradigms, perspectives, viewpoints) that are the geneses for push back (McGregor, 2011a) [26]. This internal self-awareness during problem solving is made possible through reflexivity (Berger, 2015) [27], to be discussed.

Nicolescu drew on several quantum physics principles to formulate TD ontological resistance. He explained that conventional scientists define Reality in terms of resistance (Nicolescu, 2014, p. 203 [9]); they assume that the process of finding the singular reality (using positivism, the scientific method, and exclusive logic) involves resistance to contradictory viewpoints. Nicolescu challenged this assumption by turning to quantum physics, chaos theory and complexity theory.

\subsubsection{Quantum vacuum}

First, classical physics assumes a vacuum is empty and devoid of air, life and energy. There is nothing. Quantum physics, on the other hand, assumes a vacuum is at its lowest energy level and full of potential. There is something. Entering the quantum void will not kill anyone because life and energy are there - just waiting to emerge (McGregor, 2011a) [14]. Nicolescu (2006a, 2011) [21. 22] used this construct to envision people moving into and through a zone of nonresistance (i.e., the quantum void) where they voluntarily try to receive others' perspectives, paradigms, ideologies, value premises, and belief systems; in effect, they temporarily let go of aspects of how they currently know the world to make room for the emergence of co-created, complex (interwoven) knowledge through cross fertilization and embodiment (McGregor, 2011a, 2018) $[10,14]$.

\subsubsection{Discontinuity}

Second, classical physics' notion of continuity assumes that people cannot pass from one point to another without passing through all intermediate points - nothing can be skipped or left out (e.g., cannot break a chain of evidence). Nicolescu (2011) [22] eschewed this premise and used instead the quantum principle of discontinuity (i.e., the gap of potentialities). This holds that the boundaries between Realities do not have to touch or intersect for people to cross over and through to each other. And, no bridges are required so people can cross the gap (empty space) as is needed with multi and interdisciplinary initiatives (McGregor, 2011a) [14]. Instead, transdisciplinary ontology assumes knowledge generation happens in this gap (Nicolescu, 2002) [2].

In more detail, new things emerge in this "rupture between Realities" (McGregor, 2011a, p.7 [14]). Nicolescu (2016) [17] called "the chasm between two levels of Reality the Valley of Astonishment . . . [a place of] The New Renaissance" (p. 15). People are expected to set aside their reservations and resistance 
and step into the quantum void trusting that things will emerge. Nicolescu conceived this as an undulating middle ground where intellectual fusion can occur because barriers are temporarily lowered among people (imagine a lava lamp; see McGregor, 2018) [10]. People intermingle in this zone of nonresistance with their interactions mediated by the Hidden Third (e.g., art, culture, faith). These aspects of life act as the lubricants for the evolution and creation of trans-Reality and new complex knowledge (Nicolescu, 2010) [28]. To clarify, the neologism trans-Reality (i.e., beyond current reality to a new space) represents the new ontology (i.e., understanding of reality) that is created when aspects of the TD-Object and the TD-Subject are interwoven using the Hidden Third.

Related to discontinuity, "the different levels of Reality are energizing" (Nicolescu, 2016, p. 15 [17]) meaning they are powerfully effective (Anderson, 2014) [15]. And although each level of Reality (e.g., economic, planetary, historical) is rife with resistance, there is no resistance in the Hidden Third zone due to quantum discontinuity (as well as inclusive logic and the logic of complexity). Any discontinuity (i.e., gap) between the different levels of Reality is compensated by the continuity (enduring flow) of information held by the Hidden Third (Nicolescu, 2000, 2014) [2, 9].

\subsubsection{Incompleteness}

Third, using the quantum principle of incompleteness, Nicolescu (2006a) referenced a new relativity principle: "No Level of Reality constitutes a privileged place from where one could understand all the other Levels of Reality. A Level of Reality is what it is because all the other levels simultaneously exist" (p. 14) [21]. Reality is an "open structure" with each level of Reality considered to be incomplete, achieving some level of completeness only when considered relative to the other levels (Nicolescu, 2010, p. 23 [28]). In contrast, classical physics assumes that reality is complete and comprises fundamental entities linked by causality (i.e., continuity) (McGregor, 2011a) [14].

Furthermore, classical physics' basic principle of relativity assumes that any law of nature should always be the same regardless of the person measuring it; all laws should look the same to everyone. Also, perceptions are assumed to be true only in relation to a given observer at a given place and time - a single referential (McGregor, 2011a; Nicolescu, 2014) [9, 14]. "In the transdisciplinary vision, Reality is not only multi-dimensional, it is also multi-referential" (Nicolescu, 2000, p. 3). If something is referent it is referred to or consulted (Anderson, 2014) [15]. "One level cannot be understood in terms of the laws and concepts of another level. ... Each level must be approached, interpreted, and explained in terms of its own [fundamental] concepts and logic" (van Breda, 2008, p.6 [29].

However, this interpretation must appreciate that a level of Reality is what it is because all the other levels simultaneously exist (Nicolescu, 2002, 2010) [2, 28]. "The laws ruling one particular level of Reality are just a part of the ensemble of laws ruling all levels of Reality" (McGregor, 2011a, p. 3 [14]). Also, none of these Realities is privileged (i.e., does not have a special right, an advantage or immunity) (Nicolescu, 2002, 2010) [2, 28]. As well, in order to understand the complex open structure of trans-Reality manifesting in the Hidden Third, people have to accept that levels of Reality are not only separated, they are also connected (van Breda, 2008) [29].

\subsection{Trans-Reality and Vertical Complexity}

With all this movement in play (e.g., between, among and across disciplines and sectors and within the quantum vacuum and multiple levels of Reality), Nicolescu (2012) [30] posited that trans-Reality is plastic, meaning it is malleable and pliable. He suggested that people's freedom to act to address complex problems consists of entering into or perturbing the "movement of Reality. . . . Reality depends on us" (p. 26) [30] and its inherent plasticity enable humans to shape it.

Fourth, to accommodate this movement, Nicolescu (2006b) conceptualized vertical complexity to represent crossing several levels of Reality (e.g., economics, social, political, technology) to address a complex problem. When transiting from one level of Reality to another in the zone of nonresistance, people gain glimpses of different Realities (i.e., their eyes are wide open). "The different levels of Reality are 
Sue L. T. McGregor

Transdisciplinarity and Transpraxis

accessible to human knowledge thanks to the existence of different levels of perception" (Nicolescu, 2000, p. $3[20])$. These momentary glimpses may serve to create "reciprocal enrichment that may facilitate the understanding of complexity" (Max-Neef, 2005, p. 15 [32]).

Subsequent changes to perceptions of Realities lead to changes in perspectives on the world at which point "the world changes" (Nicolescu, 2010, p. 23 [28]). The resultant unity of knowledge (i.e., a rich new blend of objective and subjective ways of knowing and being in the world) can better address the pressing problems humanity faces (Nicolescu, 2014, 2016) [9, 17]. The process of creating a trans-Reality involves shared meaning, the mutual struggle to overcome resistance, and the emergent process of becoming, which are also core tenets of transpraxis (to be discussed). A discussion of praxis (from Karl Marx) will preface an overview of transpraxis, a conceptual extension developed by Henry and Milovanovic (1994) [7] through the work of Fredrich Nietzsche, a German philosopher from the late 1800s (Young \& Arrigo, 1999) [33].

\section{Praxis}

Praxis is part of Aristotle's conceptualization of three basic human activities: (a) theoria (thinking) to discern truth; (b) poiesis (making) leading to production; and (c) praxis (doing), which involves a rational human being taking deliberate, reflective action (Dennison, 2013; Smith, 2011) [34, 35]. Etymologically, praxis is the opposite of theory, which is a system of ideas intended to explain something. Theory is Greek theoria for 'contemplate, consider, speculate.' Praxis is Greek, 'action, doing, practice' (Harper, 2020) [24].

\subsection{Social Transformation}

Barring etymological definitions, praxis is all about "the integration of knowledge and action (theory and practice) [with one not preceding the other or of greater value] . . . but it is also much more than that" (White, 2007, p. $226[36]$ ). As a special form of action, praxis pertains "to the act of engaging, applying, exercising, realising, or practicing ideas [in addition to theorizing and philosophizing about them]" (Varey, 2005, p. 41 [37]). Praxis seeks social transformation thorough reflection and by posing questions about justice and emancipation (Nayar, 2008) [38].

Instead of being a mere act, an act of praxis shapes and changes the world (Smith, 2011) [35]. This reshaping and change can occur because praxis is a "thoughtful, practical doing [emergent from] both practice and reflection" (Dennison, 2013, para. 7 [34]). As an example of change and transformation, Evans (2015) suggested that "sustainability takes place through praxis" (p. 73) [3] with sustainability meaning protecting future generations with today's decisions.

\subsection{Truth and Moral Dispositions}

As a special form of practice, praxis is "guided by a moral disposition . . . for human flourishing" (Smith, 2011, p. 2 [35]). More than reflection, praxis refers to "action which embodies . . . a commitment to human well being and the search for truth, and respect for others. It is the action of people who are free, who are able to act for themselves" (Smith, 2011, p. 3 [35]). Praxis is thus "expressed through committed moral action . . . and practices of accountability" (White, 2007, p. 226 [36]). Schwandt (2002) [39] asserted that "praxis does not require knowledge of how to make something, but knowledge of how to be a particular kind of person; it is 'action-oriented self-understanding'" (p. 49) made possible through reflection (White, 2007) [36]. This type of practice does not mean performing or doing a task to get better at it; rather, "it is other-seeking and dialogic" (Smith, 2011, p. 4 [35]).

\subsection{Dialogic Exchanges}

Praxis is directed at other human beings (i.e., other seeking) while being engaged in by human beings (i.e., dialogic) (Smith, 2011; Varey, 2015) [35, 37]. Dialogic refers to the fact that various approaches, ideologies and paradigms can coexist with each one holding more salience in particular circumstances (Micael, 2018) 
[40]. Dialogic discourse also entails listening for implicit intentions rather than explicit meaning as do dialectics (Micael, 2018; Sennett, 2012) [40, 41]. The intent of dialogic action is "to reveal the truth [while] interacting with others and the world" (Micael, 2018, p. 235 [40]).

As a word of caution, although suitable for collaborative work, dialogic exchanges often fail to bring closure meaning issues may remain unsolved. But truths will have been revealed, which can influence future interactions (Micael, 2018) [40]. Also related to exposing truths through discourse, "through praxis, we can acquire a critical awareness of our own condition" (Varey, 2015, p. 41 [37]). And, praxis involves applying dialogic, truth-revealing "thought to the entirety of human existence" (Nayar, 2008, para. 6 [38]).

In more detail, praxis "symbolizes efforts to alter and improve the conditions in which people live, work and engage others" (Arrigo, 2006, p. 311 [13]). It strives to develop "new frames for interpretation, knowledge and action" (Nayar, 2008, para. 7 [38]). With praxis, there is no prior knowledge of the right way to realize a particular end. As people think about how to achieve the ends, they change the means. Also, as they think about something they want to change (the end), people can alter what they might aim at (the end) (Smith, 2011) [35].

In short, the means and ends are in continual interplay (Smith, 2011) [35], which is made possible because praxis has an active and dynamic character that is different in each context; thus, praxis cannot be specified in advance (White, 2007) [36]. "Language, context, values, situated meanings, dialogue, relationships and multiple interpretations all play a role in" [praxis] (White, 2007, p. 227 [36]). During praxis, context-specific "words and actions, discourses and experience [are revealed and] merge" (White, 2007 , p. $226[36])$.

\section{Transpraxis}

This section explains how the meaning of praxis changes when prefaced with the word-forming element trans. Trans is Latin trare, 'across, beyond, through, movement to another state or place.' Praxis is Greek, 'action, doing, practice' (Harper, 2020) [24]. Conjoined, transpraxis can fundamentally be defined as action, practice or doing that moves people beyond where they are now to another state or place (usually philosophically, ideologically or intellectually). This will require adjustments, change and transformation. Transpraxis, a proposed conceptual evolution, serves as a tool for the ensuing discussion of transdisciplinarity and transpraxis. This section covers deconstruction, reflexivity, resistance, transpraxis space, and contingent universalities and provisionality.

\subsection{Postmodern Twist - Deconstruction}

Transpraxis is a postmodern twist on the modernist construct of praxis (Arrigo, 2006) [13]. Modernism (1800s-1950s) was (is) the era of technological innovation and progress, imperialism, capitalism, corporateled globalization, consumerism and materialism. Postmodernism (1960s and onward) challenges the basic tenets of modernism by advocating for social movements, holism and interdependence to address the exploitation, oppression, fragmentation, alienation, dualism (e.g., us/them) and marginalization caused by modernism (McGregor, 2015) [42].

Deconstructive postmodernism is especially concerned with exposing and righting the imbalanced power relationships perpetuated through socially and politically loaded binaries (dualism) and associated discourse (McGregor, 2015) [42]. Transpraxis respects the link between theory and practice to effect change (e.g., praxis) but augments praxis with a concern for the role in transformation of dialogic, dialectics, language and binary-laden discourse. The key to transpraxis is how people talk about and act upon speech, words and grammar (i.e., tools of both oppressive and emancipative discourse) (Arrigo, 2006; Arrigo, Milovanovic, \& Schehr, 2005) [6, 43].

Transpraxis entails "deconstructing how power is expressed through words" (Bolton, 2005, p. 221 [44]). The violence of language can disempower and marginalize people and deny them opportunities to express themselves, their truths and make a difference in their world (Henry \& Milovanovic, 1996) [45]. Fortunately, 
Sue L. T. McGregor

Transdisciplinarity and Transpraxis

using dialogic exchange to reveal the power of language and deeper truths can lead to emancipation (Henry \& Milovanovic, 1996) [45] and a more just and humanistic world (Young \& Arrigo, 1999) [33].

The criminology discipline and associated practices of crime, criminals and the penal system (penology) have proven rich ground for conceptualizing transpraxis (Arrigo, 2006) [13]. Specifically, Henry and Milovanovic (1994) [7], drawing on Fredrich Nietzsche's (1968) [46] work on the master/slave dichotomy (see Young \& Arrigo, 1999) [33], proposed transpraxis as a way to deconstruct the exploitative hierarchal power relations of global capitalism (which often manifest in crime and attendant institutions) and reconstruct these relations so they are no longer exploitive. This would involve emphasizing the interdependent and intersubjective nature of human relations instead of focusing on the dynamics of power relations (Arrigo \& Bersot, 2016) [6].

\subsection{Reflexivity}

In particular, transpraxis builds reflexivity into praxis, which normally hinges on just reflection (Henry \& Milovanovic, 1994; Milovanovic, 1997) [7, 8]. Reflection and reflexivity are different. In the reflective mode, people give serious thought and consideration to an action during and after it has happened so they can gain insights and grow personally and professionally. To be reflexive, people examine their own thoughts (via introspection) as events occur and do so with a concern for their positionality (Ryan, 2005) [47], which refers to how their identity influences, and potentially biases, their understanding of and outlook on the world (Berger, 2015) [27]. In more detail, Bolton (2009) [48] explained that

reflection is learning and developing through examining what we think happened on any occasion, and how we think others perceived the event and us . . . It is looking at whole scenarios from as many angles as possible: people, relationships, situation, place, timing, chronology, causality, connections, and so on, to make situations and people more comprehensible . . . Reflexivity is finding strategies to question our own attitudes, thought processes, values, assumptions, prejudices and habitual actions, to strive to understand our complex roles in relation to others. The reflexive thinker has to stand back from belief and value systems, habitual ways of thinking and relating to others, structures of understanding themselves and their relationship to the world, and their assumptions about the way that the world impinges upon them. (p. 13) [48]

Reflexivity in transpraxis refers to "the process of a continual internal dialogue and critical self-evaluation of [one's] positionality as well as active acknowledgement and explicit recognition that this position may affect the [collaborative] process and outcome" (Berger, 2015, p. 220 [27]). To clarify, a person's positioning while working with others to address a wicked problem includes their beliefs, preferences and biases as well as any political, theoretical, and ideological stances along with their emotional responses and personal experiences with the problem at hand (Berger, 2015) [27]. Reflexivity entails each person looking back onto and into themselves to recognize and take responsibility for one's own situatedness within "[the transdisciplinary initiative] and the effect [their positioning] may have on [the problem-solving process]" (Berger, 2015, p. $220[27]$ ).

Through reflexivity, people can use transpraxis to deconstruct current practices and avoid constructing new forms of oppression and entrenched power struggles (Arrigo \& Bersot, 2016; Downes, 1996; Young \& Arrigo, 1999) [6, 33, 49]. Indeed, sometimes, in their efforts to push back against an oppressive hierarchy (e.g., rich/poor), people end up creating an entirely different hierarchy (e.g., north/south) "through the very act of negating the other's unjust control" (Arrigo \& Bersot, 2016, p. $552[6]$ ).

\subsection{Validating Resistance, Challenging Self-serving Hierarchies}

Young and Arrigo (1999) [33] offered teen bullying as a powerful example of addressing a power struggle using transpraxis. If, as a form of resistance, the teen being bullied asks someone to help her overpower the bully, the binary nature of the power struggle has not been altered (i.e., people using power over one another). However, if those involved attempted to expose and liberate both parties from the binary 
hierarchy that underpinned the power struggle (e.g., white/black, rich/poor, male/female, and young/old) then the hierarchy itself is resisted. The focus of resistance shifts from people to the power-laden hierarchies and binaries (Arrigo \& Milovanovic, 2009) [50].

To that end, transpraxis is a vehicle for effecting a more just and humanistic social order (Young \& Arrigo, 1999) [33]. It does so by exposing and deconstructing self-serving hierarchies and binaries that create and reinforces power relations (Arrigo et al., 2005) [43]. Transpraxis is "an effort to validate the act of resistance [by keeping us] continuously aware of the interrelatedness of our agency and the structures it reproduces" (Milovanovic \& Henry, 2005, p. 156 [51]). Agency refers to actions or interventions people take to produce a particular result. These actions manifest not only in behaviour but also in "talking, perceiving, conceptualizing, and theorizing" about hierarchies and binaries shaping the world (Milovanovic \& Henry, 2005, p. 156 [51]).

\subsection{Transpraxis Space}

Transpraxis is thus a dialogical and relational "co-productive space that is both 'beyond' and 'other than' the praxis of resistance" (Arrigo \& Bersot, 2016, p. 552 [6]). In this "transpraxis space" (p. 554), change has the real possibility of being radically re-formed. It is a "space of overcoming [where people can] affirm the other's humanity [and] await co-productive instantiation" (Arrigo \& Bersot, 2016, p. 553 [6]) (i.e., produce a concrete instance of a general principle or theory).

Within this space, transpraxis acts as a nonreifying (i.e., think logically) and affirmative strategy for engaging with others (Arrigo \& Milovanovic, 2009) [50]. During this engagement, people "speak about their social relations and institutions while speaking through them, conceiving them . . . as emergent processes closely bound up with creative being and becoming" (Arrigo \& Milovanovic, 2009, p. 12, [50] emphasis added).

\subsection{Contingent Universalities and Provisionality}

As noted, this engagement reflects an awareness of how social agency and resultant structures are interrelated (Arrigo \& Milovanovic, 2009; Milovanovic \& Henry, 2005) [50, 51]. Actually, transpraxis assumes that any agendas and structures that are constructed through this agency are provisional and contingent, "subject to further reflection, modification, deletion, and substitution" (Milovanovic, 1997, p. 22 [8]). Social change (informed by political agendas) is thus dependent on "contingent universalities" (Milovanovic, 1997, p. 22 $[8])$.

To clarify, universality (certainty) means being true and appropriate for all situations and shared by all people. Contingent (uncertainty) means what happens or arises is determined by conditions or circumstances that have not yet been established (Anderson, 2014) [5]. Contingent universality is a poststructuralist concept that challenges and reconceives the modernist binary of universality/particularity (Natter, 2008) [52]. In that spirit, it reflects a "fecund perspective from which to reflect upon a range of . . . outcomes" (Natter, 2008, p. 109 [52]) instead of narrowing expectations to one particular outcome suitable for everyone (universal).

People drawn to contingent universality aspire to render possibilities and outcomes that are "more inclusive, more dynamic and more concrete" (Natter, 2008, p. 137 [52]). By association, the transpraxis space needs to "be filled, contested, and reconfigured through contingent and partially determined social relations, practices and meanings" (Natter, 2008, p. 141 [52]). Arrigo et al. (2005) [43] further recommended replacing universality and modernistic grand narratives (undisputed truths) with contingent and provisional truths. Making room for truth to be able to change - depending on what arises during discourse and its deconstruction - respects the emergent nature of transpraxis dialogic exchanges. 
Sue L. T. McGregor

Transdisciplinarity and Transpraxis

\section{Transdisciplinarity and Transpraxis}

In their essence, both transdisciplinarity and transpraxis are against dualism and binary hierarchies. The TD methodology was formulated to help create new knowledge to address the complex, wicked problems emergent from the fallout of binary-laden modernism (e.g., capitalism, consumerism, corporateled globalization, neoliberalism, technological innovation and progress, and imperialism) (Nicolescu, 2014) [9]. Transpraxis has evolved as a way to help both the oppressor and oppressed push back against binary hierarchies (e.g., rich/poor, north/south, male/female, nature/nurture, white/Native) and associated discourse that maintains the status quo to the detriment of people, other species and the planet (Arrigo \& Bersot, 2016) [6].

Nicolescu (2014) [9] clearly stated that "transdisciplinarity means transgression of duality, opposing binary pairs" (p. 209). He formulated a ternary partition (TD-Object, TD-Subject and the Hidden Third) to challenge the longstanding modernist binary partition of Object versus Subject. Transpraxis was also conceived as a way to confront dualism. In their discussion of transpraxis, Arrigo et al. (2005) [43] argued that those in power rely on binaries, dualities, and associated discourses to build and sustain self-serving hierarchies and the status quo (e.g., man over woman, the deserving rich over the unworthy poor, the value-free objective over the value-laden subjective). Transpraxis strives to make the dualities and hierarchies the focus of resistance instead of the people espousing the dualities; people are affirmed while their binary-informed practices are renounced (Arrigo \& Milovanovic, 2009) [50].

Also, Arrigo et al. (2005, p. 139 [43]) claimed that the "path to transpraxis [is through the use] of dynamic theory (e.g., chaos theory [and complexity theory])." Related concepts include "role perturbations, nonlinearity, instability, dissipative structures, 'fractal spaces,' and 'far-from-equilibrium' conditions" (Bolton, 2005, p. 221 [48]). Like mindedly, transdisciplinarity is predicated on the dynamic theories of chaos theory, complexity theory, and quantum physics. Related concepts include incompleteness, discontinuity, inclusive logic, quantum vacuum, emergence, embodiment, self-organizing, cross fertilization, multiple realities, and a mediating, unifying force (Nicolescu, 2002, 2011, 2014) [2, 9, 22].

Not surprisingly, key aspects of transpraxis readily align with Nicolescuian transdisciplinarity and vice versa (see Table 1) perhaps paving the way to a new conceptualization of transdisciplinary transpraxis. Each aspect is now discussed.

\subsection{Reflexivity}

First, bringing reflexivity to TD work is desirable. Reflexivity (i.e., focusing on one's position and how it informs interactions and discourse) (Berger, 2015) [27] smooths the way for trans-Reality to exist and new knowledge to emerge. Once people drop their resistance to others' perspectives and positions, they can enter into dynamic dialogue intent on addressing complex, wicked problems knowing full well that resistance is a normal stance in such situations. Reflexivity is akin to self-appraisal (Berger, 2015) [27], which is deeply necessary when dealing with resistance in the fertile middle ground where trans-Reality is trying to emerge amongst contradictory Realities. "Any intense exchange requires a deeper knowledge of one another's positions and a flexible attitude with regard to one's own position" (Pohl \& Hirsch Hadorn, 2008, p. 116 [53]).

In an axiomatic aside, although values come into play here, Nicolescu (2010) [28] did not see the need for an axiology axiom because transdisciplinary values emerge from the Hidden Third. He felt that TD values are more important than people's personal values. Cicovaki (2009) [54] and McGregor (2011b, 2018) $[20,26]$ thought otherwise suggesting that the values people bring to the table (i.e., their positioning) should not be discounted. Both values and subjectivity in transdisciplinary work can impact positionality (Berger, 2015) [27]. 
Table 1: Alignment between transdisciplinarity and transpraxis.

\begin{tabular}{|c|c|}
\hline Reflexivity & $\begin{array}{l}\text { Be aware and question one's internal positioning while working } \\
\text { with others and how this might influence the collaborative } \\
\text { process and outcome }\end{array}$ \\
\hline $\begin{array}{l}\text { Deconstructing } \\
\text { Discourse }\end{array}$ & $\begin{array}{l}\text { Reveal and confront power perpetuated by self-serving hierar- } \\
\text { chies and binaries (i.e., validate the person, resist hierarchy); } \\
\text { expose the power of language. }\end{array}$ \\
\hline Dialogics & $\begin{array}{l}\text { Listen carefully to discern people's positionality; acknowledge } \\
\text { coexistence of divergent approaches with one holding salience } \\
\text { in a particular circumstance }\end{array}$ \\
\hline Revealing Truths & $\begin{array}{l}\text { Pursue and reveal truths by deconstructing discourse; truths } \\
\text { are vulnerable in discourse and readily threatened }\end{array}$ \\
\hline $\begin{array}{l}\text { Transformational, } \\
\text { Transcendent Space }\end{array}$ & $\begin{array}{l}\text { Affirm each others' humanity and overcome resistance leading } \\
\text { to the creation of a new fecund space from which to effect } \\
\text { radical change and transformation through mutual struggle } \\
\text { and becoming }\end{array}$ \\
\hline $\begin{array}{l}\text { Interplay between } \\
\text { Means and Ends }\end{array}$ & $\begin{array}{l}\text { The process of solving (means) and any solutions to complex, } \\
\text { wicked problems (ends) are alive and changing; provisional and } \\
\text { contingent }\end{array}$ \\
\hline $\begin{array}{l}\text { Binaries } \\
\text { Confronted }\end{array}$ & $\begin{array}{l}\text { Tearing down binary walls creates space for unity of knowing } \\
\text { leading to a unity of knowledge emergent from the meeting and } \\
\text { intermingling of minds in a fecund space }\end{array}$ \\
\hline
\end{tabular}

\subsection{Deconstructing Discourse}

Second, maintaining awareness of the power of language in perpetuating and revealing self-serving hierarchies and dualities also makes sense during TD work. People will enter the quantum void (zone of nonresistance) with well-entrenched self-interests and political and social positions. As they attempt to engage with others around complex problems, their choice of words (discourse and communication) will reflect their interests and positions. People have to listen carefully to each other's articulations and respect that their goal is to validate the person while taking issue with the hierarchy or dualism being presented. Transpraxis strives to make these the focus of resistance instead of the people espousing them (Arrigo \& Milovanovic, 2009; Young \& Arrigo, 1999) [33, 50].

\subsection{Dialogics}

Third, the transpraxis concern for dialogics instead of dialectics is also germane to TD work, which deals with wicked problems (McGregor, 2019) [11]. Dialectics is Latin dialektike tekhne, 'the art of debate' (Harper, 2020) [24]. It concerns the interaction between multiple ideologies and paradigms with one establishing priority over the others. Through tension, mediated conflict, a competitive process and compromise (using thesis, antithesis and synthesis), people strive for closure and resolution (Micael, 2018; Sennett, 2012) [40, 41]. However, a dialectic approach alone is inappropriate for wicked problems because it uses exclusive, deductive logic (not TD's inclusive logic) and can inadvertently exclude a key element in the solution due to the need to make concessions (even if they are mutually agreed-to concessions).

Dialogic is Latin dialogus, 'conversation; converse, dialogue or speak across and between' (Harper, 2020) 
Sue L. T. McGregor

Transdisciplinarity and Transpraxis

[24]. Unlike the competitive win-lose mindset of dialectics, the dialogic process entails people staying with the mess so that any ultimate actions are grounded in reality. The intent of a dialogue is to listen and make meaning together (Jones, 2007) [55]. Compared to dialectics, dialogic processes hold that various paradigms, ideologies, worldviews and approaches can coexist with each one holding more salience in particular circumstances. During the dialogic process, people purposefully listen for latent and implicit messages instead of just overt and explicit communications (dialectics) (Jones, 2007; Micael, 2018; Sennett, 2012) [40, 41. 55]. This way, people can better discern where a speaker is really coming from when asserting a position informed by their positionality. Attendant insights depend on reflexivity and help unearth hidden agendas and interests. Dialogic aligns with TD inclusive logic because both are concerned with making space for diverse points of view to live and work together.

\subsection{Revealing Truths}

Fourth, through interacting with each other and respective worlds, people using the dialogic process can better reveal truths (Arrigo, 2006; Jones, 2007) [13, 55]. The transdisciplinary unity of knowledge (i.e., unite subject with object via the Hidden Third) required to address complex problems depends on truth (Nicolescu, 2014, 2016) [9, 17]. In fact, transdisciplinarity is about "the pursuit of truth" with the nature of truth dependent both on the way the world is and the way people are and think about the world (Cicovaki, 2009, p.4 [54]). Transpraxis also entails revealing truths and does so through careful deconstruction of discourse (Arrigo, 2006; Arrigo et al., 2005) [13, 43].

Nicolescu (2016) strived to expose "binary thought [as] one of several possible pathways towards truth" (p. 133) [17] asserting that binary logic and truths in isolation "are deadly" (p. 134) [17]. Indeed, the truth is considered a vulnerable imperative of contemporary, modernistic discourse (along with language, argument and voice imperatives) and is readily threatened and muddied (Alexander, 2019) [56]. Dialogic talking with each other during the transdisciplinary problem-solving process (wherein hierarchical binaries are confronted) has a truth-revealing, educational and enlightening purpose. "The ideas of the various participants are heard, taken up and jointly considered" (Mercer \& Howe, 2012, p. 14 [57]). A more holistic picture of truth can emerge.

\subsection{Transformational, Transcendent Space}

Fifth, the transpraxis space is described as more than mere resistance (e.g., push back and struggle). Things can be overcome in this space and radical change can occur when people affirm each other's humanity and work together to instantiate (manifest in real time) an idea, concept or claim (Arrigo \& Bersot, 2016) [6]. The transpraxis space is affirmative with people engaging each other using logic in such a way that they speak about relationships and institutions while speaking through them. This dynamic process can lead to changes in both relationships and institutions; it is a transformational space wherein people can transcend to a new space and position (Arrigo \& Milovanovic, 2009) [50], which is the essence of transdisciplinarity too (Nicolescu, 2014) [9].

Indeed, transdisciplinarity's zone of nonresistance (i.e., the Hidden Third) is similar in nature to transpraxis space in that it helps people transcend their original stance on a problem. People try to set aside how they know the world so they can temporarily become open to others' perspectives. The intent is to use (a) inclusive logic so everything is considered and (b) the logic of complexity to weave divergent ideas into something new. Both transpraxis and transdisciplinarity value emergence and processes of becoming and being in a fecund (highly fertile) space (Arrigo \& Milovanovic, 2009; Nicolescu, 2002, 2014) [2, 9, 50].

To clarify, transpraxis becoming alludes to the chaotic state of something coming into existence (i.e., changing to and moving toward) with chaos theory assuming that chaos is order emerging - just not predictably. Nietzsche, the inspiration for transpraxis (Arrigo \& Milovanovic, 2009; Young \& Arrigo, 1999) $[33,50]$, felt that becoming does not produce fixed entities like being, because becoming entails perpetual, chaotic change while 'to be' intimates happening and stable. Nietzsche, as a philosopher of becoming, viewed reality as a continual flow of change with being "an empty fiction" (as cited in Cox, 1999) [58]. 
Nicolescu (2005) [23] similarly used the term in-vivo transdisciplinary knowledge meaning it is alive and always becoming, always in-formation, just not predictably.

\subsection{Interplay between Means and Ends}

Sixth, Smith's (2011) [35] notion that both the process (means) and the solution (ends) are alive and changing during praxis is also a good fit with transdisciplinarity and transpraxis (an extension of praxis). TD assumes that both the knowledge and problems and the people trying to address the issue are alive and changing as they work together toward knowledge emergence (McGregor, 2018; Nicolescu, 2002, 2014) $[2,9,10]$. Transpraxis similarly assumes that anything that is created is provisional and contingent making it ripe for opportunities to be modified upon reflection (Milovanovic \& Henry, 2005) [51] and reflexivity (Henry \& Milovanovic, 1994; Milovanovic, 1997) [8, 45]. Knowledge and relationships are alive and always in-formation (McGregor, 2018) [10] with what emerges contingent on what happens during the transdisciplinary process in transpraxis space.

\subsection{Binaries Confronted}

Seventh, the transpraxis principle of contingent universality, which confronts self-serving hierarchies and binaries (Milovanovic, 1997; Natter, 2008) [8, 52], aligns with transdisciplinarity's premise of unity of knowledge to understand the world. The unity of knowledge construct was formulated to confront the fragmentation evident in dualism (Object over Subject). Unity requires a ternary partition (3-part structure) that entails (1) the intertwining of the objective (scientific knowing) with (2) the subjective (human knowing) via (3) a unifying hidden force (Nicolescu, 2014, 2016) [9, 17] (see Figure 1). To that end, transdisciplinarity and transpraxis allow for a range of possible outcomes emergent from the fecund space where diverse minds intermingle to address complex, wicked problems using inclusive, unifying and emergent processes (Natter, 2008; Nicolescu, 2011) [22, 52]. Confronting binaries tears down the walls that are separating different ways of knowing thereby creating spaces for the unity of both knowing and knowledge.

\section{Conclusions}

This paper provided overviews of Nicolescuian transdisciplinarity (especially ontology), praxis, and transpraxis. When juxtaposed, it became evident that augmenting transdisciplinarity with transpraxis and vice versa is a noteworthy addition to both strands of thought. Transdisciplinarity gains reflexivity, dialogic exchange, transpraxis space, contingent universalities and provisionality, and the notion of deconstructing self-serving hierarchies. Transpraxis gains a rich methodology for creating new knowledge emergent from deconstructing self-serving hierarchies and binaries. It is enriched with the zone of nonresistance, the unifying Hidden Third, and a richer notion of resistance in the form of multiple levels of Reality. In the future, researchers and practitioners are encouraged to build on the narrative shared in this paper and conceptualize the neologism transdisciplinary transpraxis as a new phenomenon.

Funding: This research received no external funding.

Conflicts of Interest: The author declares no conflict of interest.

\section{References}

[1] McGregor, S. L. T. (2017). Challenges to transdisciplinary collaboration: A conceptual literature review. Integral Leadership Review, 17(1). http://integralleadershipreview.com/15402-challenges-of-transdisciplinarycollaboration-a-conceptual-literature-review/

[2] Nicolescu, B. (2002). Manifesto of Transdisciplinarity [K-C. Voss, Trans.]. Albany, NY: SUNY Press.

[3] Evans, T. L. (2015). Transdisciplinary collaborations for sustainability education: Institutional and intragroup challenges and opportunities. Policy Futures in Education, 13(1), 70-96. 
Sue L. T. McGregor

Transdisciplinarity and Transpraxis

[4] Mitchell, R., \& Moore, S. (2015). Planetary praxis and pedagogy: Transdisciplinary approaches to environmental sustainability. In R. Mitchell \& S. Moore (Eds.), Planetary Praxis and Pedagogy (pp. 9-40). Rotterdam, the Netherlands: Brill/Sense.

[5] Mitchell, R., \& Moore, S. (2018). Transdisciplinary child and youth studies: Critical praxis, global perspectives. World Futures, 74(7-8), 450-470.

[6] Arrigo, B. A., \& Bersot, H. Y. (2016). Revolutionizing academic activism: Transpraxis, critical pedagogy, and justice for a people yet to be. Critical Criminology, 24, 549-564.

[7] Henry, S., \& Milovanovic, D. (1994). The constitution of constitutive criminology: A postmodern approach to criminological theory. In D. Nelken (Ed.), The Futures of Criminology, (pp. 110-133). London, England: Sage.

[8] Milovanovic, D. (1997). Postmodernist versus the modernist paradigm: Conceptual differences. In D. Milovanovic (Ed.), Chaos, Criminology, and Social Justice, (pp. 3-28). Westport, CT: Praeger.

[9] Nicolescu, B. (2014). From Modernity to Cosmodernity. Albany, NY: SUNY Press.

[10] McGregor, S. L. T. (2018). Philosophical underpinnings of the transdisciplinary research methodology. Transdisciplinary Journal of Engineering ES Science, 9, 182-198.

[11] McGregor, S. L. T. (2019). Transdisciplinary curriculum: Educational philosophy and rationale. Integral Leadership Review, 19(1). http://integralleadershipreview.com/16751-transdisciplinary-curriculum-educationalphilosophy-and-rationale/

[12] Rittel, H., \& Webber, M. (1973). Dilemmas in a general theory of planning. Policy Sciences, 4(2), $155-169$.

[13] Arrigo, B. (2006). Praxis. In E. McLaughlin \& J. Munice (Eds.), The SAGE Dictionary of Criminology, (2nd ed.) (pp. 301-311). Thousand Oaks, CA: Sage.

[14] McGregor, S. L. T. (2011a). Demystifying transdisciplinary ontology: Multiple levels of reality and the Hidden Third. Integral Leadership Review, 11(2). http://integralleadershipreview.com/2011/03/demystifyingtransdisciplinary-ontology-multiple-levels-of-reality-and-the-hidden-third

[15] Anderson, S. (Ed.). (2014). Collins English Dictionary (12th ed.). Glasgow, Scotland: Harper Collins.

[16] Subjective vs objective. (2019). In Diffen.com. https://www.diffen.com/difference/Objective_vs_Subjective (accessed March 9, 2020).

[17] Nicolescu, B. (2016). The Hidden Third (W. Garvin, Trans.). New York, NY: Quantum Prose.

[18] Mitchell, C. B. (2004, August 13). The logic of utilitarianism [Letter to the editor]. The Telegraph. https://www.telegraph.co.uk/comment/letters/3609586/The-logic-of-utilitarianism.html (assessed March 9, 2020).

[19] Sinnott-Armstrong, W. (2019). Consequentialism. In E. N. Zalta (Ed.), Stanford Encyclopedia of Philosophy. Stanford, CA: Stanford University. https://plato.stanford.edu/entries/consequentialism/\#ClaUti (accessed March 9, 2020).

[20] Nicolescu, B. (2000). Transdisciplinarity and complexity: Levels of reality as a source of indeterminacy. CIRET Bulletin, 15, Article 4. http://ciret-transdisciplinarity.org/bulletin/b15c4.php (accessed March 9, 2020).

[21] Nicolescu, B. (2006a). Heisenberg and the Levels of Reality. European Journal of Science and Theology, 2(1), 9-19.

[22] Nicolescu, B. (2011). Methodology of transdisciplinarity - Levels of reality, logic of the included middle and complexity. In A. Ertas (Ed.), Transdisciplinarity, (pp. 22-45). Austin, TX: TheAtlas Publishing.

[23] Nicolescu, B. (2005). Towards Transdisciplinary Education and Learning. Paper presented at the Metanexus Institute Conference, 4-8 June. Philadelphia, PA.

[24] Harper, D. (2020). Online etymology dictionary. http://www.etymonline.com/

[25] Cole, A. (2006). Motueka Catchment Futures, Transdisciplinarity, a Local Sustainability Problématique and the Achilles-Heel of Western Science. Paper presented at the 5th Australasian Conference on Social and Environmental Accounting Research, 22-24 November. Wellington, New Zealand.

[26] McGregor, S. L. T. (2011b). Transdisciplinary axiology: To be or not to be. Integral Leadership Review, 11(3). http://integralleadershipreview.com/3388-transdisciplinary-axiology-to-be-or-not-to-be/ 
[27] Berger, R. (2015). Now I see it, now I don't: Researcher's position and reflexivity in qualitative research. Qualitative Research, 15(2), 219-235.

[28] Nicolescu, B. (2010). Methodology of transdisciplinarity- Levels of Reality, logic of the included middle and complexity. Transdisciplinary Journal of Engineering and Science, 1(1), 17-32.

[29] Van Breda, J. (2008). Exploring non-reductionism and levels of Reality: On the importance of non-separability of discontinuity and continuity of the different levels of Reality. The Global Spiral, $9(4)$. https://www.metanexus.net/exploring-non-reductionism-and-levels-reality-importance-non-separabilitydiscontinuity/

[30] Nicolescu, B. (2012). Transdisciplinarity: The Hidden Third, between the subject and the object. Human and Social Studies, 1(2), 13-28.

[31] Nicolescu, B. (2006b). Transdisciplinarity: Past, present and future. In B. Haverkort \& C. Reijntjes (Eds.), Moving Worldviews - Reshaping Sciences, Policies and Practices for Endogenous Sustainable Development, (pp. 142-166). Leusden, Netherlands: COMPAS Editions.

[32] Max-Neef, M. A. (2005). Foundations of transdisciplinarity. Ecological Economics, 53, 5-16.

[33] Young, T. R., \& Arrigo, B. (Eds.). (1999). Dictionary of Critical Social Science (1st ed.). Boulder, CO: Westview Press.

[34] Dennison, W. C. (2013, August 29). It's all Greek to me: The terms 'praxis' and 'phronesis' in environmental philosophy [Blog]. https://ian.umces.edu/blog/2013/08/29/its-all-greek-to-me-the-terms-praxis-and-phronesisin-environmental-philosophy/ (accessed March 9, 2020).

[35] Smith, M. K. (2011). What is praxis? In M. K. Smith, M. E. Doyle, \& T. Jeffs (Eds.), The Encyclopaedia of Informal Education. http://www.infed.org/biblio/b-praxis.htm (accessed March 9, 2020).

[36] White, J. (2007). Knowing, doing and being in context: A praxis-oriented approach to child and youth care. Child Youth Care Forum, 36(5-6), 225-244.

[37] Varey, R. J. (2005). Marketing for sustainable living. In R. Mitchell \& S. Moore (Eds.),Planetary Praxis and Pedagogy, (pp. 41-71). Rotterdam, the Netherlands: Brill/Sense.

[38] Nayar, P. L. (2008). Praxis. In Online Encyclopedia.com. https://www.encyclopedia.com/social-sciences-andlaw/sociology-and-social-reform/sociology-general-terms-and-concepts/praxis (accessed March 9, 2020).

[39] Schwandt, T. (2002).Evaluation Practice Reconsidered. New York, NY: Peter Lang.

[40] Micael, H. (2018). How to Build a Better World for Our Generation. Indianapolis, IN: Dog Ear.

[41] Sennett, R. [Speaker]. (2012, February 29). The Architecture of Cooperation [Video file]. https://www.youtube.com/watch?v=tcXE4NEgLn8 (accessed March 9, 2020).

[42] McGregor, S. L. T. (2015). Postmodernism and home economics: Revitalizing the conversation. Kappa Omicron Nu FORUM, 19(1). http://www.kon.org/archives/forum/19-1/mcgregor5.html

[43] Arrigo, B. A., Milovanovic, D., \& Schehr, R. C. (2005). The French Connection in Criminology. Albany, NY: SUNY Press.

[44] Bolton, M. J. (2005). [Review of the book The French Connection in Criminology, by B. A. Arrigo, D. Milovanovic \& R. C. Schehr]. Criminal Justice Review, 30(2), 220-223.

[45] Henry, S., \& Milovanovic, D. (1996). Constitutive Criminology: Beyond Postmodernism. Chicago, IL: SAGE.

[46] Nietzsche, F. (1968). The Will to Power (W. Kaufmann and R. J. Hollingdale, Trans.). New York, NY: Random House.

[47] Ryan, T. (2005). When you reflect are you also being reflexive? Ontario Action Researcher, 8(1), Article \#2. https://oar.nipissingu.ca/PDFS/V812E.pdf (accessed March 9, 2020).

[48] Bolton, G. (2009). Reflective Practice. Thousand Oaks, CA: SAGE.

[49] Downes, D. (1996). [Review of the book The Futures of Criminology, by D. Nelken (Ed.)]. British Journal of Sociology, 47(2), 360-365.

[50] Arrigo, B. A., \& Milovanovic, D. (2009). Revolution in Penology. Lanham, MA: Rowman and Littlefield.

[51] Milovanovic, D., \& Henry, S. (2005). Constitutive penology. In M. Bosworth (Ed.), Encyclopedia of Prisons and Correctional Facilities, (pp. 154-157). London, England: Sage. 
Sue L. T. McGregor

Transdisciplinarity and Transpraxis

[52] Natter, W. (2008). Is universality the object of globalization? Political geographies of contingent universality. In H. Dahms (Ed.), No Social Science without Critical Theory, (pp. 109-153). Bingley, England: Emerald Group.

[53] Pohl, C., \& Hirsch Hadorn, G. (2008). Methodological challenges of transdisciplinary research. Natures Sciences Sociétés, 16(2), 111-121.

[54] Cicovaki, P. (2009). Transdisciplinarity as an interactive method. Integral Leadership Review, 9(5). http://integralleadershipreview.com/4549-feature-article-transdisciplinarity-as-an-interactive-method-acritical-reflection-on-the-three-pillars-of-transdisciplinarity

[55] Jones, A. (2007, September). Speaking Together: Applying the Principles and Practice of Dialogue. Reading, England: University of Reading.

[56] Alexander. R. (2019). Whose discourse? Dialogic pedagogy for a post-truth world. Dialogic Pedagogy, 7. doi:10.5195/dpj.2019.268 (accessed March 10, 2020).

[57] Mercer, N., \& Howe, C. (2012). Explaining the dialogic process of teaching and learning. Learning, Culture and Social Interaction, 1, 12-21.

[58] Cox, C. (1999). Nietzsche. Berkeley, CA: University of California Press.

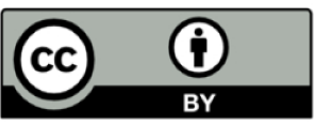

Copyright (c) 2019 by the author. This is an open access article distributed under the Creative Commons Attribution License (https://creativecommons.org/licenses/by/4.0/), which permits unrestricted use, distribution, and reproduction in any medium, provided the original work is properly cited.

\section{About the Author}

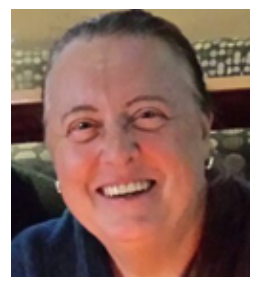

Dr. Sue L. T. McGregor (PhD, IPHE, Professor Emerita) is a Canadian home economist (nearly 50 years) retired after 30 years from Mount Saint Vincent University, Halifax NS. She has a keen interest in home economics philosophy and leadership along with transdisciplinarity, research paradigms and methodologies, and consumer studies and education. She is a ATLAS Fellow, a Rhoda H. Karpatkin International Consumer Fellow, and she received the TOPACE International Award (Berlin) for distinguished international consumer scholar, especially as consumer educator using a transdisciplinary perspective. Dr. McGregor is the recipient of Kappa Omicron Nu's (KON) Marjorie M. Brown Distinguished Professor Award (home economics leadership) and is Docent in Home Economics at the University of Helsinki (lifetime appointment in recognition of international leadership). She published Understanding and Evaluating Research (SAGE) in 2018. Her scholarship is at www.consultmcgregor.com 